\title{
ASSESSING THE POSSIBILITY OF IMPLEMENTING TOOLS OF TECHNICAL ANALYSYS FOR REAL ESTATE MARKET ANALYSIS
}

\author{
Justyna Brzezicka, M. Sc. \\ Faculty of Geodesy, Geospatial and Civil Engineering \\ University of Warmia and Mazury in Olsztyn \\ e-mail:justyna.brzezicka@uwm.edu.pl
}

\begin{abstract}
Technical analysis (TA) and its different aspects are widely used to study the capital market. In the traditional approach, this analysis is used to determine the probability of changes in current rates on the basis of their past changes, accounting for factors which had, have or may have an influence on shaping the supply and demand of a given asset. In the practical sense, TA is a set of techniques used for assessing the value of an asset based on the analysis of the asset's trajectories as well as statistical tools.

The work assumes three research objectives: 1) a review of tools applied in technical analysis, 2) an attempt at implementing selected tools of technical analysis for analyzing the real estate market (REM), 3) an assessment of the possibilities of implementing selected tools for assessing the real estate market on the example of the Olsztyn residential real estate market. The research hypothesis is a presumption regarding the possibility of implementing tools used in traditional technical analysis for the analysis of the real estate market accounting for the natural limitations and specifics of the market.

The work extends scientific achievements in the part regarding the methods and tools of analyzing the real estate market as well as the connections between the real estate market and the capital market.
\end{abstract}

Keywords: technical analysis, real estate market, trend analysis.

JEL Classification: E39; O18, R00.

Citation: Brzezicka J., 2016, Assessing the Possibility of Implementing Tools of Technical Analysys for Real Estate Market Analysis, Real Estate Management and Valuation, vol. 24, no. 2, pp. 85-96.

DOI: 10.1515/remav-2016-0016

\section{Introduction}

Technical analysis, in addition to fundamental and portfolio analysis, is a tool used for analyzing the capital market and forecasting (ZiELONKA 2006, p. 19). Portfolio analysis is used to diversify investment risk by constructing a complex asset portfolio (ŁUNIEWSKA 2012, p. 11), while accounting for systematic (market) and specific (non-market) risk (SZYSZKA 2009, p. 24). Fundamental analysis is used to determine the internal value of an asset on the basis of macroeconomic, sector and economicfinancial (microeconomic) analysis, and is a long-term investment technique (EUNIEWSKA 2012, p. 11). Technical analysis, on the other hand,_is a tool of short-term analysis, and is used to predict turning points in asset prices, determine the probability of changes in current rates on the basis of their changes in the past, and, generally speaking, for the observation of market trends (EUNIEWSKA 2012, p. 67). TA is used in regards to the capital market, though its application appears to be possible also in the analyses of the real estate market while accounting for its specific features. This observation is of a hypothetical nature, and the deliberations and studies carried out in the present work aim to establish, by an attempt at verifying the posed hypothesis, if there are grounds for 
implementing selected tools of TA for the real estate market. The work is of a theoretical and cognitive nature, as well as being an overview in terms of the basic deliberations regarding the relationships between the capital and real estate markets. At the same time, it does not touch on the historical scope and is limited to selected practical applications of TA for the analysis of the REM (practical scope of studies).

\section{Review of literature}

Technical analysis is a set of techniques developed in the XX century, with significant achievements in the last few dozen years (see ARMS 1997; GATELY 1998; MURPHY 1998, 1999; ACHELIS 2001; EDWARDS, MAGEe, BASSETTI 2007; PlumMER 2009). The popularity of TA results from the fact that it can be applied in many capital and forward markets, and be adapted to any chosen type of transaction and time (MURPHY 1999, pp. 7-8). This results from the fact that capital markets are strongly connected with each other. As MURPHY (1998, p. 3) points out, the analysis of any single financial market is impossible in isolation from other markets: it is worth seeking relationships between the American stock market, the forward market for gold and the bond market, the exchange rate of the dollar, or stock trends on the Japanese stock exchange. MURPHY $(1998$, p. 3) also notes that the relationships are not only of an intrasectoral (capital market) character but also intersectoral, as all sectors of world finances influence one another. This observation leads one to seek relationships between the capital market and the real estate market (Channel I - hard relationships), as well as make an attempt at referring dependencies observed on the capital market to the real estate market (Channel II - fluid relationships).

Following the path of hard connections, it is worth turning our attention to the numerous works and studies confirming the dependency of the capital market on the real estate market (e.g. GYOURKO, KeIM 1992; DeLisle 2002; CASE, Quigley, SHILLER 2005). As indicated by KuCHARSKA-STASIAK (2006, p. 93 and onwards), the real estate market is a part of the capital market; real estate is physical capital and thus is, in itself, the object of investment (e.g. BRYX, MATKOWSKI 2002; ELDRED 2009). In mature markets, there is a real estate asset market serving as a comparison or even alternative to the stock market (GELTNER et al. 2013, p. 11). The capital market and the real estate market are double interrelated processes of a causal character: on one hand, the crises on the real estate market led to the economic crisis (SORNETTE, WOODARD 2010; BLANCHARD 2009; BARBERIS 2011, 2013), while on the other hand, real estate is a security of capital (Eldred 2009, p. 3) and serves to transfer funds in the real estate sector as well as to secure the possessed assets and investments (AUGUSTYNIAK et al. 2012; BRUEGGEMAN, FISHER 2008, p. 3).

Following the path of fluid connections, it is worth drawing attention to the features differentiating the capital market from the real estate market as far as structures and operational mechanisms are concerned. There are fewer transactions on the REM in a given unit of time than on the capital market; moreover, each subject of a transaction on the real estate market is different (ZYGA 2015) and remains in deficit, at the very most being similar (BARAŃSKA 2008, p. 4), whereas on the capital market each "object" is the same (BRZEZICKA, WIŚNIEWSKI 2016a), somewhat "standardized" (GDAKOWICZ, 2015, p. 150). Moreover, there are no homogenous places and times of transactions being made on the real estate market (BEEEJ, CELLMER 2014, p. 6), trading does not involve a good but the right to it. Moreover, the capital market comes close to being a perfect market, whereas the real estate market is an imperfect market of low transparency (WIDŁAK et al. 3013, p. 140) and is highly specific (KULESZA, BEŁEJ 2015; CELLMER, SZCZEPANKOWSKA 2014, p. 2; RENIGIER-BIŁOZOR 2013, p. 57).

Further theoretical and scientific deliberations, carried out accounting for the above features differentiating the markets, lead us to accept research limitations which are an interpretation of the specifics of the real estate market. At the same time, Murphy's earlier mentioned arguments (1999, pp. 7-8) regarding the possibility of flexibly implementing methods of technical analysis to other markets makes it possible to look into the techniques, methods and tools of market analysis in greater detail, as well as looking into the assumptions of technical analysis.

Three convictions lie at the base of technical analysis (MURPHY 1999, p. 2): 1) market action discounts everything; 2) prices move in trends, 3) history repeats itself. These assumptions, although they pertain to the capital market, are also valid in reference to the real estate market. In accordance with the first assumption, prices reflect the market mechanism and the laws of supply and demand. This assumption is flagship for fundamental analysis (see KRZYWDA 2010, p. 55; HOTT, MONNIN 2008; PANFIL, SZABLEWSKI 2013, p. 112), though it is also significant to technical analysis - it is not trends and 
formations that influence prices, but prices that influence trends and analytical formations by means of a group of price-forming determinants of the market. An expression of this is not the seeking of causes of price trajectories by TA, but instead its turning points (MURPHY 1999, p. 3). Another rationale behind using TA for market analysis pertains to the strong conviction regarding the trends of real estate prices. This assumption is also key in regards to the real estate market, on which market trends become the basis for or are connected with real estate valuation (TSATSARONIS, ZHU 2004, p. 69), forecasting, and other analyses (KUCHARSKA-STASIAK, SCHNEIDER, ZAŁĘCZNA 2009, pp. 101-104). An example can be the conviction as to the strictly increasing tendency of real estate prices at the time of the speculative boom (RouBINI, MIHM 2010, Chapter 1). This is also an excellent example of history repeating itself - booms and busts occur one after another, whereas price bubbles are created despite understanding the genesis and mechanisms of earlier cycles and crises (SHILLER 1990, 2009).

\section{Data and methods}

\subsection{Tools of technical analysis}

The basic tools of technical analysis are groups of methods connected with: 1) trends, 2) formations, read based on graphs and 3) indicators. The best known graphs are those of stock prices which record the prices of stocks and numbers of sessions (see ŁUNIEWSKA 2012, p. 69; MURPHY 1999, pp. 35-47; ACHELIS 2001), as well as candlestick charts (e.g. WAGNER, MATHENY 1994; NISON 1994), which are similar in nature to statistical box plots (ACZEL 2011, p. 50). Candlestick charts in reference to the Polish real estate market were designed by GDAKOWICZ $(2014 ; 2015)$. These charts are used to assess a price trends (declining, inclining or horizontal) by presenting changes in the listings of stocks in the accepted time interval, e.g. daily or weekly (see MURPHY 1999, pp. 35-47). The precise analysis of trends is possible by calculating moving averages (e.g. GUNASEKARAGE, POWER 2001; ElLIS, PARBERY 2005) and observing price channels and various trend formations: continuation or reversal patterns (MURPHY 1999; EDWARDS, MAGEE, BASSETTI 2007), with the simultaneous use of a few methods. These observations are confirmed with the aid of calculated indicators, e.g. Bollinger Bands. Literature contains reports confirming the use of the mentioned methods for real estate market analysis (QI, WAN, ZHANG 2011; citation based on summary of article). In a further section of the present work, particular attention is given to the technical analysis of a trend and formations, and to a lesser degree indicators.

\subsection{Subject and scope of studies}

The subject of studies were residential real estate prices on the Olsztyn real estate market. The period under study covered a 10-year time frame: 2004-2013. The data selection criteria pertained to real estate floor surface area: purchase-sale transaction prices of flats $25-100 \mathrm{~m}^{2}$ were accepted for the study. Limitations in terms of the ownership rights to real estate and the parties to the transaction were not made. The database covered 16,033 transactions. The study was carried out on monthly average prices calculated based on the arithmetic mean of all prices recorded in the Register of Real Estate Prices and Values of the Olsztyn City Hall in accordance with the assumed scope of the study. Monthly aggregates of prices were used as the basis for the study as opposed to hourly, daily or weekly ones as is the case on the capital market because: 1) this is the commonly assumed time interval for studying the REM, 2) due to the specifics of the REM described above, 3) due to the long time frame of the data (120 analytical periods). Nevertheless, prices on the real estate market are registered on a daily basis, which is why an attempt was made to carry out technical analyses in the selected problematic subperiod on daily data (the details have been described in the part of the work regarding research results).

\subsection{Study aim}

The accepted database and scope of studies appear to be particularly attractive in terms of trend analysis as a speculative bubble took place on the market during the assumed time frame (see BRZEZICKA, WIŚNIEWSKI 2016A). Other types of analyses (fundamental analysis of capital markets, mixed analyses, prognostic models) were not able to determine the turning points of price trajectories from an ex ante perspective, becoming visible in the ex post perspective when the bursting of the speculation bubble took place. These premises became the basis for formulating the study aims and took on a utilitarian dimension. They include: 1) the presentation of methods of the technical trend 
analysis; 2) assessing whether the turning points of price trajectories in a speculation period can be predicted with the use of technical analysis, 3) determining the breaking point in a given interval of time foreseeing the burst of the speculation bubble in 2008 .

\subsection{Tools of technical trend analysis}

Understanding a trend in reference to the real estate market is different than in the case of the capital market. In the technical and narrower sense, a trend on the real estate market is a trajectory of prices (see ROEHNER 1999; ZHOU, SORNETTE 2006; BRZEZICKA, WIŚNIEWSKI 2016b) set out based on a certain aggregate of prices in a unit of time, e.g. the arithmetic mean or medians (see KULESZA, BEŁEJ 2014, pp. 214-215). In a broader sense, price trends are the tendencies taking place on the real estate market and in its surroundings (ŹRÓBEK 2006, pp. 24-25). In the case of the technical analysis of the capital market, a trend is simply the directions of the market - which way it is moving (MURPHY 1999, p. 49), whereas in the specialized approach, a trend is comprised of the peaks and troughs of activity on the price charts of an asset (MURPHY 1999, pp. 49-50). They are determined using resistance and support lines and their breaks, trend channels and channel lines, and turning points of trends and formations (see ŁUNIEWSKA 2012, p. 68).

\section{Study results}

First, the usefulness of applying a logarithmic scale for the analysis of real estate prices was assessed (see Fig. 1). The logarithmic scale is widely used by stock market analysts to construct stock charts, as it allows for covering a large range of values and has a high axis span. It is applied to illustrate the dynamics of changes if large differences occur between the analyzed values, and to show percentage changes in value, e.g. in the case of a logarithmic scale, a change from 10 to 20 (increase of 100\%) is shown by the same segment as in the case of a change from 20 to 40 , or 40 to 80 (numerical example: MURPHY 1999, p. 40). The database of transaction prices has been presented using the arithmetic (linear) scale (Fig. 1, left), logarithmic scale (Fig. 1, middle), and logarithmic scale with adapted axis intervals (Fig. 1, right). Visual analysis indicates that in the case of real estate prices, it is appropriate to leave analyses in the arithmetic scale due to reflecting actual market prices. The logarithmic scale can be applied to complement the analyses, but not as the basic measure. The dynamics of real estate prices is smaller than the dynamics of stock prices; the highest monthly price is approximately three times the minimum. Further studies will be carried out in the linear scale as the main scale, and in some cases, the logarithmic scale will also be used to complement the analyses.
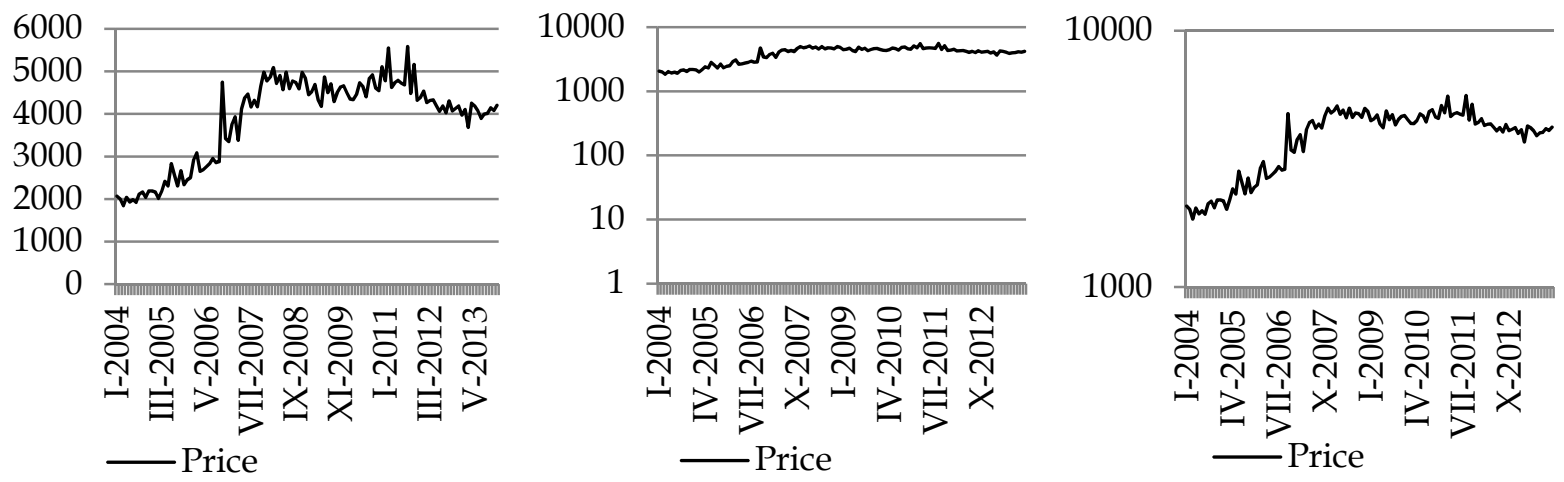

Fig. 1. The appropriateness of using the logarithmic scale for market analysis. Source: own elaboration.

The next step assessed the possibility of carrying out trend analysis on the real estate market based on tools of capital market technical analysis. Figure two shows a larger image of the data from Figure 1 - left; data from Figure 1-right have been shown in Figure 3. Trend analysis using technical analysis was carried out on both of these graphs. The turning points, as well as upper and lower extreme points were key. The most important elements have been indicated in color and described in a later part of the text. 


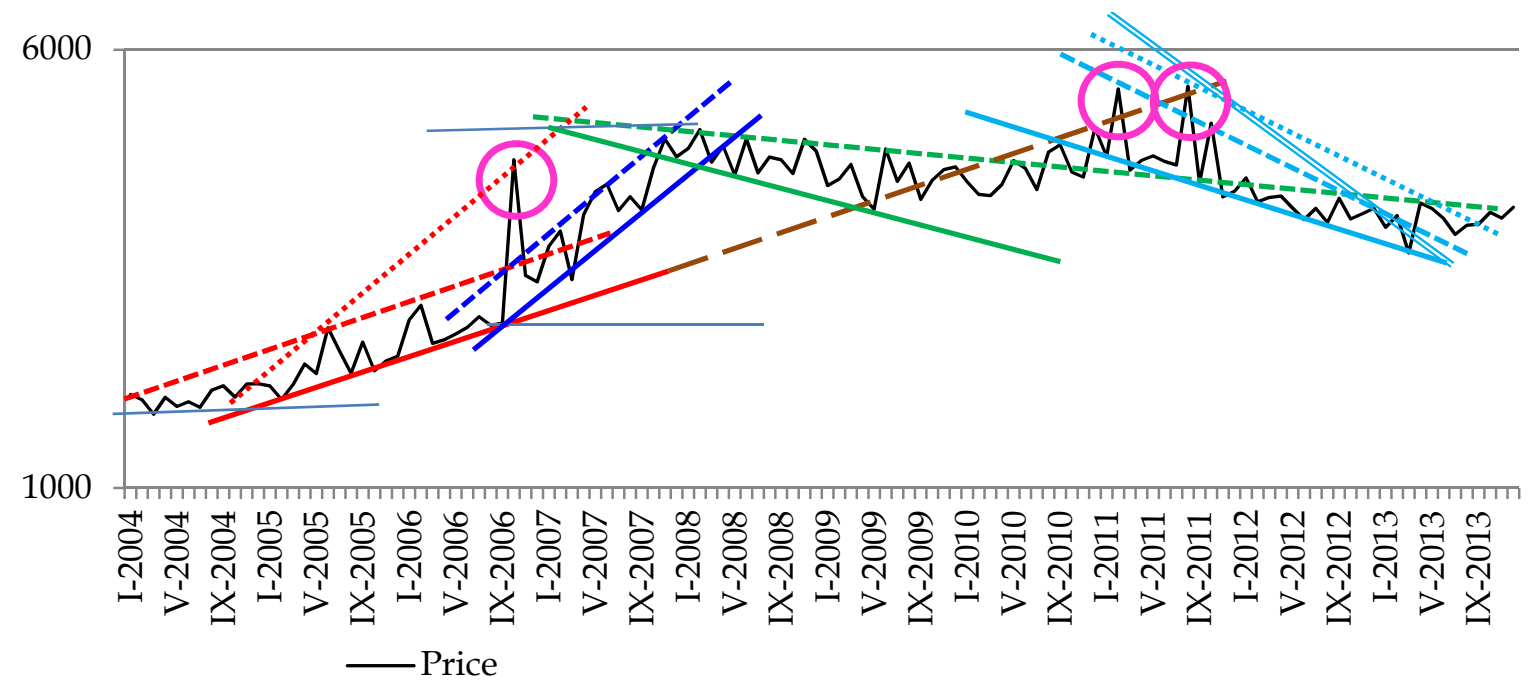

Fig. 2. Technical analysis of real estate market based on the arithmetic scale. Source: own elaboration.

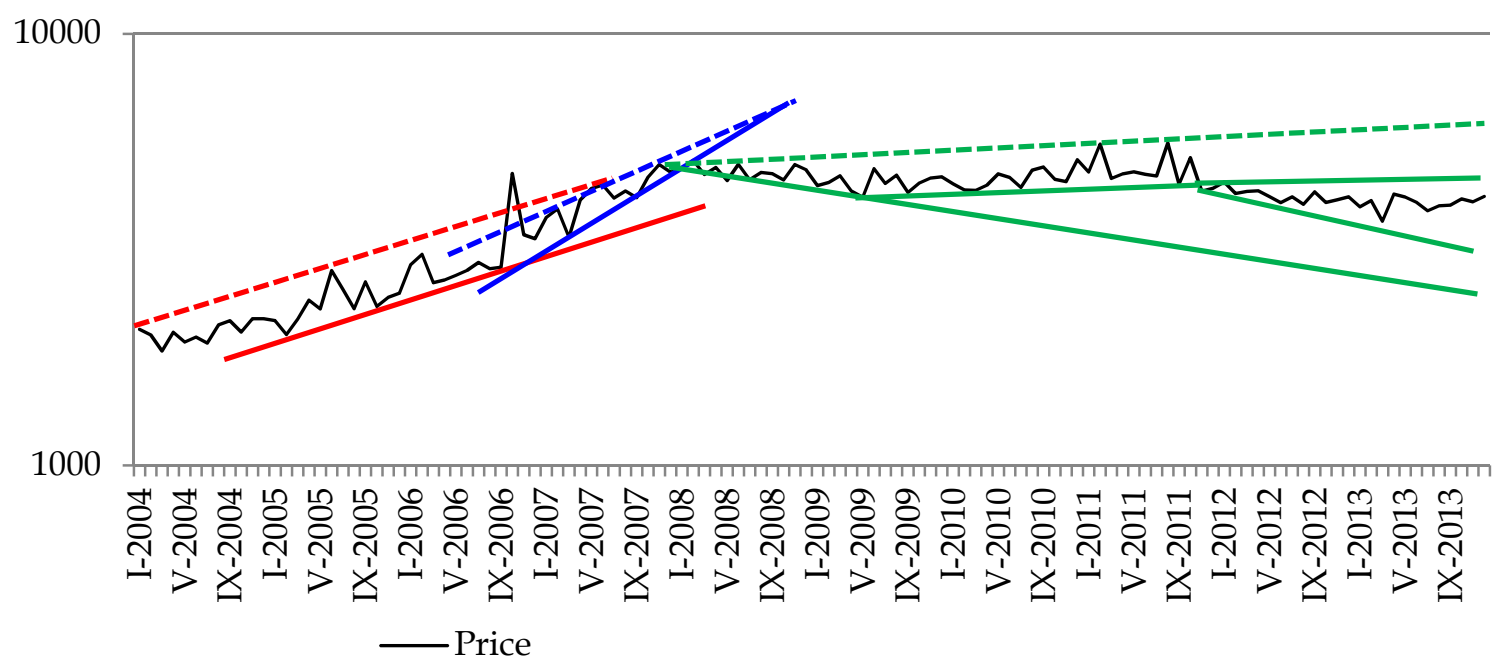

Fig. 3. Technical analysis of real estate market based on logarithmic scale. Source: own elaboration.

For data from 2004 to 2006, a trend channel with an upward trend was set out (red lines, Figs. 2 and 3). In October 2006, a significantly higher price was noted (pink circle, Fig. 2), and next, the trend channel line was observed to break on the upside, thus changing the dynamics of the upward trend (steeper angle) (navy blue lines, Fig. 2). In this light, the "peak" in 2006 forecasted further increases and changes in the rate of increases. In February 2008, the peak price at a level exceeding $5,000 \mathrm{PLN} / \mathrm{m}^{2}$ was reached, and this signaled a break in the trend on the downside, initiating slight decreases (Fig. 2).

This mechanism is known to technical analysis. Developed by Dow (Nelson 1903, Dow 1920, on the basis of MURPHY 1999, pp. 26-27), it assumes a three-phase change of the main trend. First, the accumulation phase occurs, based on buying stocks by experienced investors when bad information had already been discounted by the market. The second phase is accompanied by numerous new decisions regarding the purchase of stocks, made based on the technical analysis of the upward trend. The third phase is characterized by the massive involvement of investors on the market, optimistic reports in the media, and investment optimism. In this phase, mature and rational investors begin to sell stocks and the price falls. This theory can be partially explained by the mechanism of dynamic increases in prices and their drops, however it is not unique in its nature. In reference to the real estate market, similar theories exist explaining the mechanism behind the creation and bursting of price bubbles (see e.g. RODRIGUE 2013). In accordance with the assumptions of technical analysis, the trend is continued until the occurrence of clear indicators showing that it has reversed. Different results for this period of analysis were observed when analyzing the graph constructed on the basis of the 
logarithmic scale (Fig. 3). The period 2006-2008 is characterized by an ascending triangle formation (MURPHY 1999, p. 119), forecasting the continuation of the trend and further price increases. In the ex post perspective, the interpretation turned out to be wrong. Also interesting is the observance of a change in the levels of support and resistance (Fig. 2) - the lower level of the channel, which is the support line (period 2005-2007, red color), becomes the upper resistance line of graphs in the period from the middle of 2009 to the end of 2011 (brown line). This was noted, but the angle of incline of the line is not adequate to the analyzed formation, as the levels of support and resistance usually have horizontal trajectories (MURPHY 1999, p. 50).

Further analyses show that, in the years 2008-2009, an inverse triangle formation took place (see Fig. 2) (MURPHY 1999, pp. 123-124). This is an untypical formation of the triangle; its basic version involves the peak of the triangle being located right of its arms, and depending on the market situation (upward or downward trend) and the location of its peak (ascending or descending triangle) is interpreted differently (EUNIEWSKA 2012, p. 80). The inversion of the triangle formation as in Fig. 2 (green color), is interpreted as the loss of control of the market, dictated by emotions. In accordance with the stance taken by ARMS (1997, p. 1), technical analysis is beneficial to those who will make logical use of the emotional nature of the market. In the case of the formation of an inverse triangle, changes in volume, which increases along with an increase in the amplitude of prices, are also assessed (MURPHY 1999, pp. 123-124). In reference to this formation, the course of volume trajectories was assessed. Volume was defined as the number of purchase-sales transactions entered into in the analyzed time interval. The study indicated that the volume remains at a relatively stable level. The inverse triangle formation (Fig. 2) was noted in the period IX-2007 to V-2010 (33 months) in the first variant, and XI-2007 to V-2010 (31 months) in the second variant. In both cases, standard deviation amounted to 13 transactions with an average of 56 and 57 transactions per month, which gives a variation coefficient at the level of $23 \%$.

The last stage of the technical analysis of a trend - the period between 2011-2013, is difficult to interpret; there are problems with establishing the levels of support and resistance, while the means of establishing them will influence and determine specific patterns. Analytical difficulties resulting from properly establishing the trend line, trend channel, and levels of support and resistance can be seen in Figures 2 and 3 in the form of green and blue lines.

The conclusions which come from the carried out trend analysis clearly indicate that technical analysis makes use of schemes and tools the application of which in reference to the real estate market has a loose and unclear character (e.g. blue lines in Fig. 2). The shape of the formations results from the means and accuracy of setting out lines and the interpretation of the market situation, and thus has more of a subjective nature. Moreover, the patterns are significantly spread out over time - one pattern is a period of a few months up to as many as two years; thus, in order to be able to carry out interpretation, the end of this pattern and beginning of the next must be observed. Moreover, in the case of time delays in the influx of market information, as well as delays in discounting the available information by the market, the forecasting of real estate prices and establishing turning points of price trajectories becomes a very imprecise market analysis tool. For example, in the period of the bursting of the shallow speculation bubble on the analyzed market, i.e. at the beginning of 2008 , a clear basic pattern forecasting a trend change - the head and shoulders top, did not occur (MURPHY 1999, ŁUNIEWSKA 2012; OSLER, CHANG 1995). What is more, the carried out studies are dependent on the assumed time interval; for a different interval, the study may provide other conclusions.

In order to clarify the results in the period of the speculation bubble burst, a technical analysis of the market in a daily interval was carried out. A 3-month period of time from January to March 2008 was accepted for the analysis. The highest price for real estate on a monthly basis was noted in February 2008, thus February and the month preceding and following the peak price were selected for analysis. Prices in a daily interval were obtained as arithmetic means of all transactions noted on a given day. Daily prices and daily volumes have been presented in Figure 4, whereas Fig. 5 presents a box plot on a daily basis. In the analyzed period, three schemes were observed: in January 2008 an upward trend channel was observable until Feb. 2, 2008 (red color, Fig. 4), in February 2008 a change displayed in the form of a trend channel with an almost horizontal character (with a slightly upward tendency) took place on the market (blue color, Fig. 4), while in March 2008, the formation of a symmetrical triangle was observed (green color, Fig. 4). A long-term channel with a decreasing tendency was also charted (light blue color, Fig. 4) in the period when the short-term channel displayed an increasing tendency. Based on the carried out analysis, the change of market price 
trajectories in February 2008 became visible and price decreases were noticeable. However, it is worth noting that the peak price on Feb. 4, 2008 was noted based on one transaction, which can lead to mistakes in interpretation. Moreover, the analysis of box plots (analogical candlestick charts) (see Fig. 5) does not indicate a dynamic change in price trajectories, and even based on the constructed chart, a period of higher real estate price stability is observable in February than in January and March.

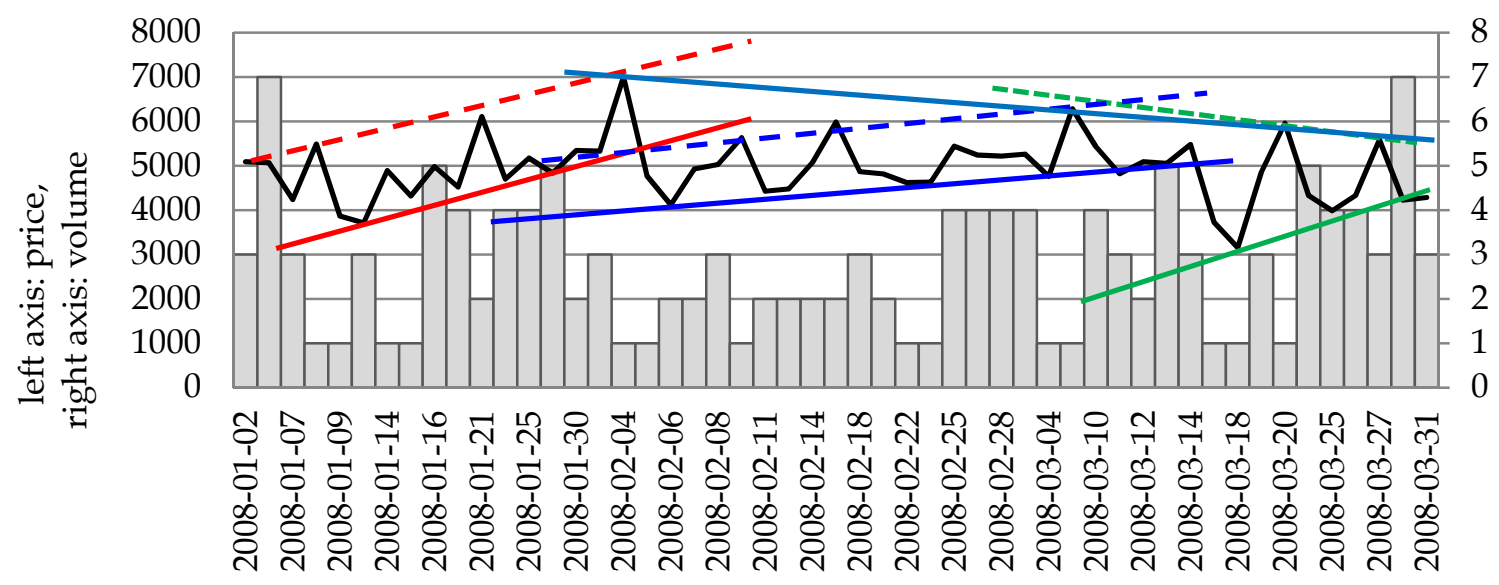

$\square$ Volume $\quad$ Price_Arithmetic average

Fig. 4. Technical analysis of real estate market based on the daily interval in the period Jan. 1, 2008 to Mar. 31, 2008. Source: own elaboration.

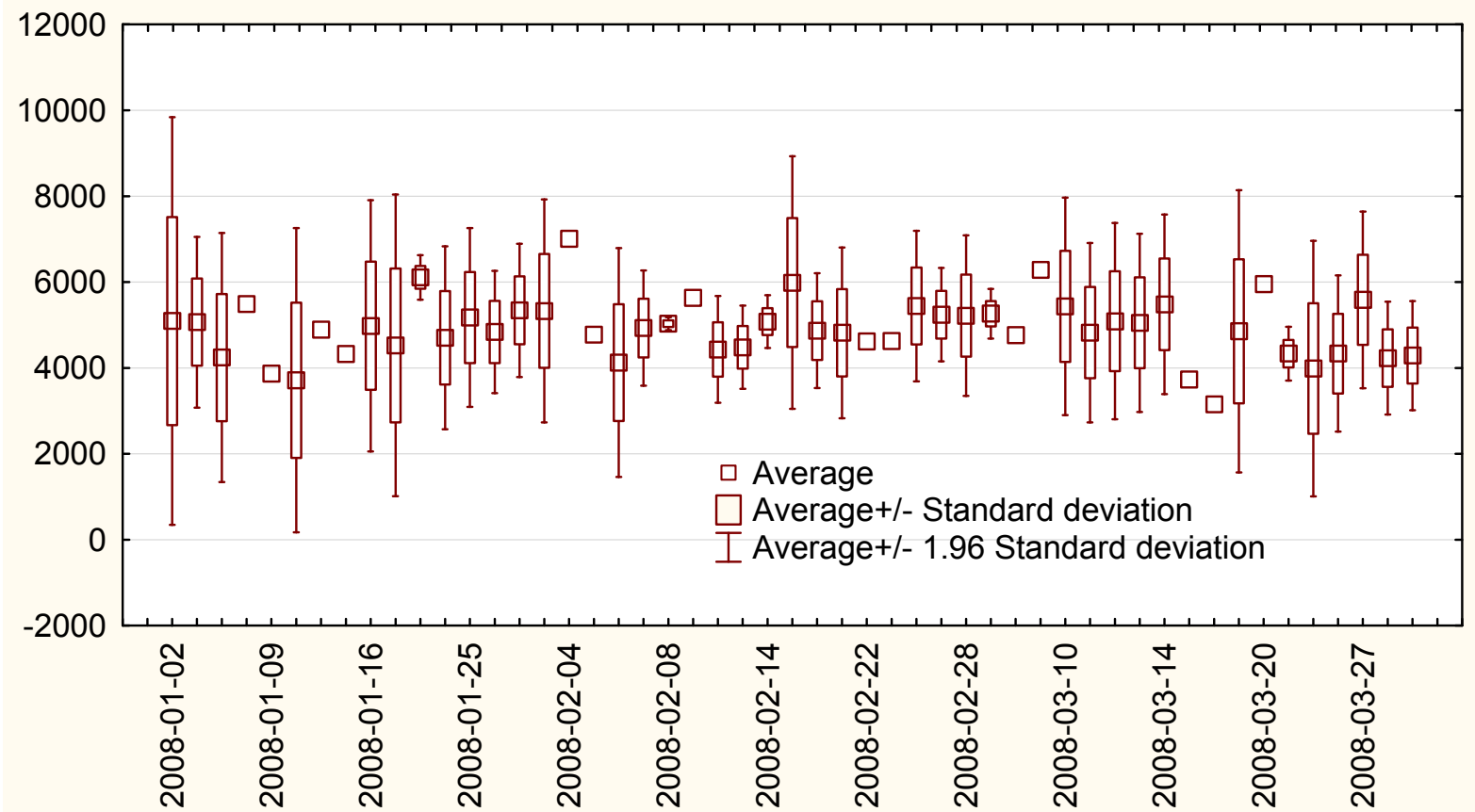

Fig. 5. Box plots based on the daily interval in the period Jan. 1, 2008 to Mar. 31, 2008. Source: own elaboration.

Conclusions which can be drawn from the carried out study confirm the supplementary nature of technical analysis on the real estate market, which may be one of many, but not the sole tool for analyzing transaction prices. As a result of the analysis, information about the occurrence of an inflection point of price trajectories (price breaking point) was obtained, but the analysis may be imperfect due to the lack of a specific sustained decrease after reaching the breaking price. The macroeconomic and social situation, and assessment of the condition of sectors connected with real estate (financial sector, building sector, etc.) ought to be indicated as factors supplementing the analysis. 
In a further stage of the studies, another tool of technical analysis was analyzed, i.e. Bollinger's Band (e.g. BOLLINGER 1992; LIU, HUANG, ZHENG 2006; ŁUNIEWSKA 2012, pp. 87-89). It is comprised of two bands which are variable in time, setting out the course of trend trajectories. The upper line is the sum of the periodic moving average $k$ and standard deviations $m$ of $k$ value. The lower line is the difference between the periodic moving average $k$ and standard deviations $m$ of $k$ value. When implementing the method for the real estate market, moving averages calculated based on the arithmetic mean of all prices available in the subsequent analyzed periods (in months) were used. Usually two standard deviations $(m=2)$ are used based on the two sigma rule, according to which the range of 2 standard deviations upwards and downwards of the average covers $95 \%$ of observations (STANISZ 2006, p. 122; ACZEL 2011, pp. 36). Prior to calculating Bollinger's Band, the trajectories and smoothing degree of the 3-, 6- and 12-period moving average was assessed (see Fig. 6).
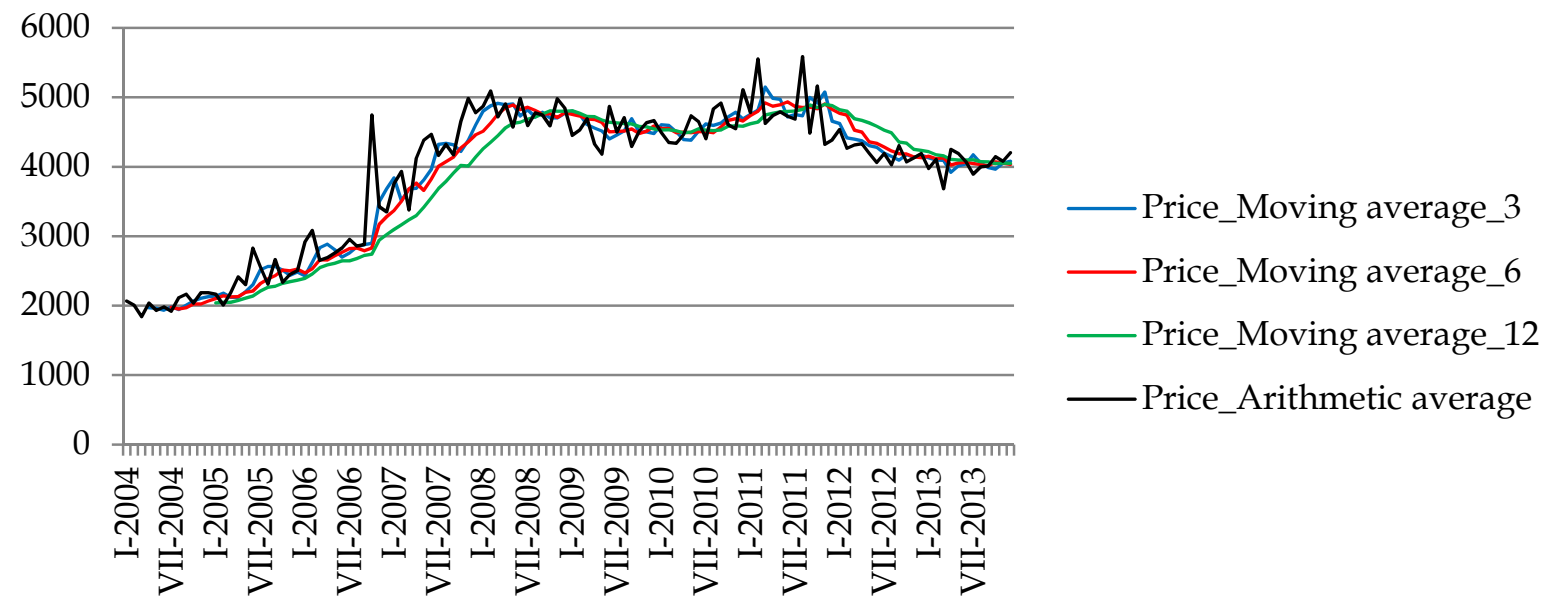

Fig. 6. Moving average and arithmetic mean of monthly market prices. Source: own elaboration.

A three-period moving average was assumed in order to assess whether the period of 1 quarter will make it possible to observe significant changes in price trajectories. Three-period (quarterly) moving averages were constructed based on the arithmetic average from all transactions in the next analytical period (month). Standard deviations were also calculated for three periods, the same as those which the moving average pertained to. The results have been compiled in Figure 7. The calculations show that the presented tools designed in accordance with the above described methodology cannot be fully applied to the real estate market due to low accuracy. The results are determined by values of standard deviation which changes dynamically due to the heterogeneous character of the real estate market described above.
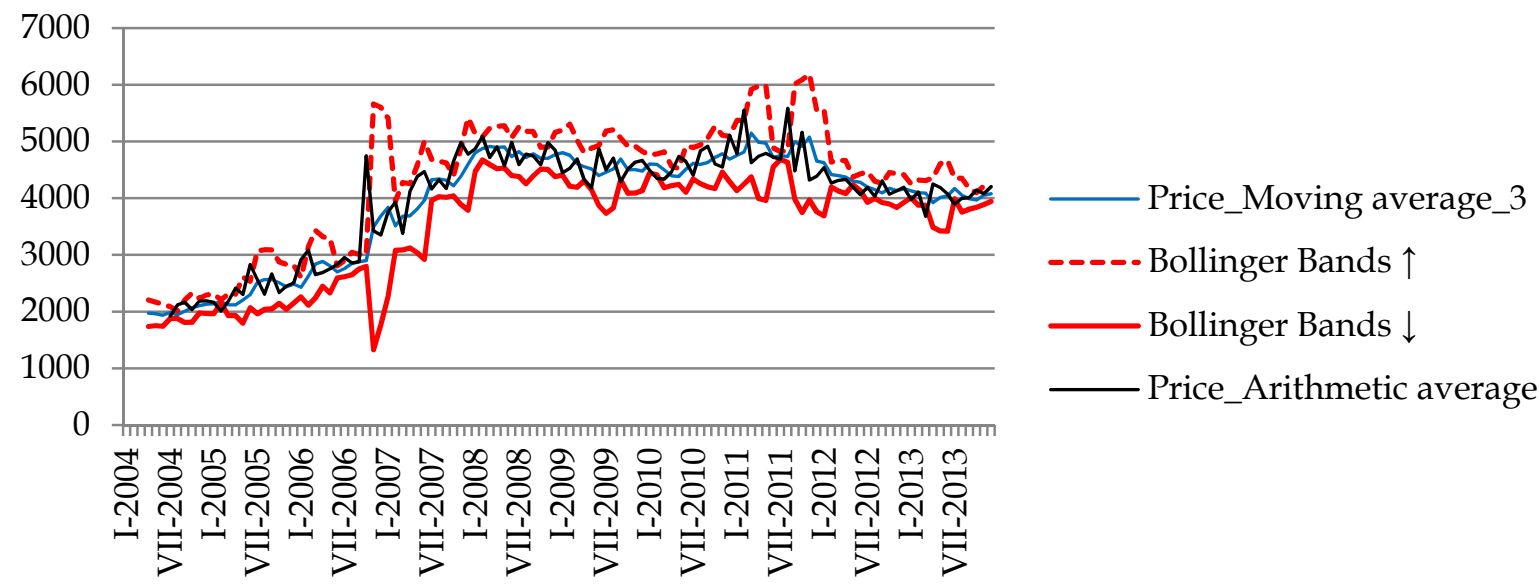

Fig. 7. Bollinger's Band. Source: own elaboration.

Calculating Bollinger's Band based on two standard deviations is correct only when the distribution of the random variable will be a normal distribution, as only then will the assumption that approximately $95 \%$ of the value of the variable will fall into the calculated range be fulfilled. The normality of distribution of average monthly prices was assessed using the Lilliefors and Shapiro- 
Wilk tests. The results of the test, along with a histogram, have been presented in Figure 8. The interpretation of results is as follows: the zero hypothesis of normal distribution ought to be rejected; the analyzed distribution is not a normal distribution, $p$-value $<0.01$. The variability of real estate prices in the 10-year period is too large to talk of a normal distribution. The results of the carried out study, based on the accepted calculation methodology, clearly confirm that the presented tool cannot be applied to the analyzed real estate market.

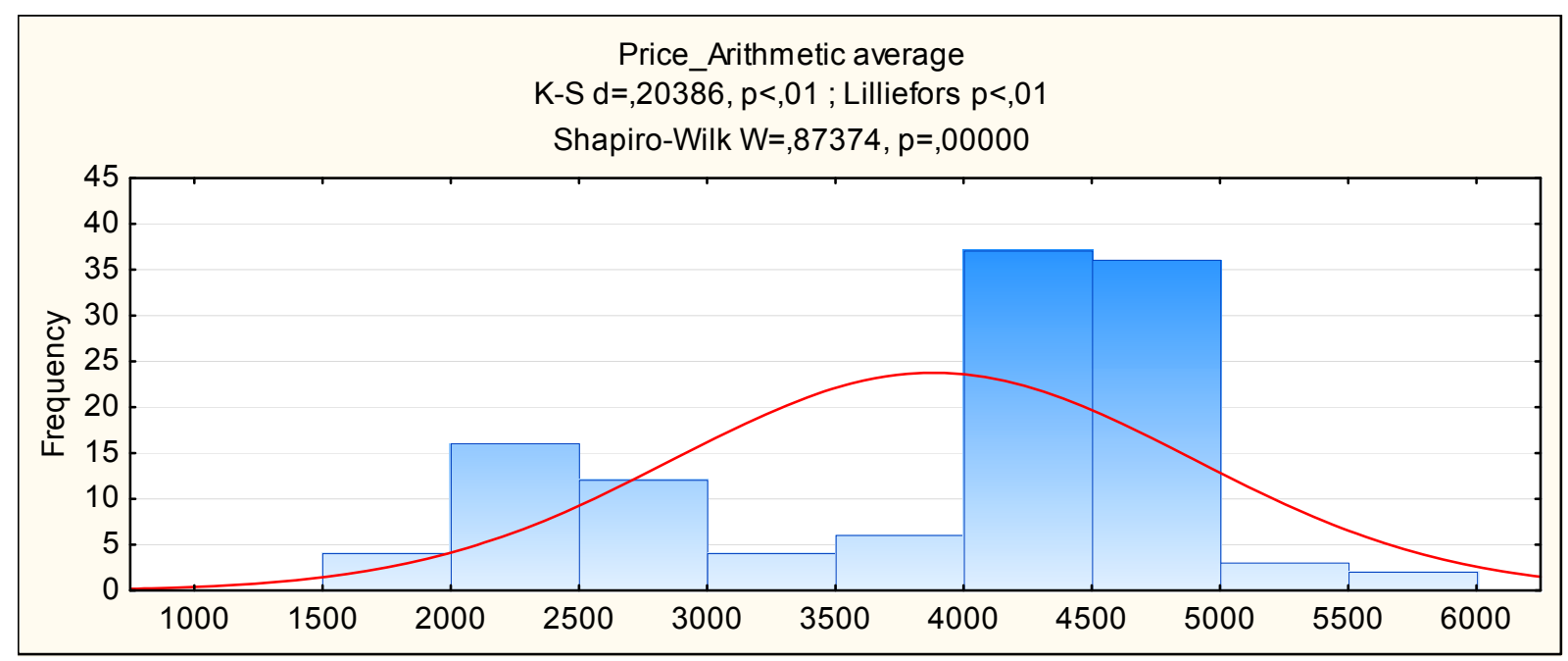

Fig. 8. Normality tests and histogram. Source: own elaboration.

\section{Summary and conclusions}

The carried out research makes it possible to make a few observations.

Firstly, the specific nature of the real estate market is not favorable to and does not allow for, based on the assumptions made, the full implementation of tools of technical analysis for the analysis of the real estate market. Elements which make implementation difficult on the side of the real estate market are: the heterogeneous structure of the real estate market, the significant differentiation of prices and fact that the subjects of trade are not identical, variable time and place of making transactions, highly variable volume in a constant time interval, information delays of the market and delays in discounting information of the market, and low market transparency. Elements making implementation difficult on the side of technical analysis are: the shot-term nature of analyses, which cannot be transferred to the real estate market in a simple manner, low accuracy and precision of the conducted analyses, and strong subjective character of analyses connected with the experience possessed by the analyst and familiarity with the market. The actual main aim of technical analysis i.e. determining the probability of changes in courses on the basis of changes in the past - involves a high dose of risk and uncertainty.

Secondly, in light of the carried out analyses, in accordance with the assumed methodology, the study hypothesis regarding "the possibility of implementing tools used in traditional technical analysis for analyzing the real estate market" cannot be fully verified, even through a prism of market limitations and the specifics of the real estate market, and can serve only as one of the complementary criteria. Those tools which were subjected to assessment did not provide clear results. Such specifics call for the precise selection of tools and methods to decrease the degree of uncertainty of the carried out analyses. Over the course of studies, two of the first aims were realized, while the third aim set out for the research section was realized only partially ("determining the breaking point in an interval of time forecasting the burst of the price bubble in 2008"), as the observations were not precise and the tools were not sufficient for diagnosing and making forecasts regarding the real estate market, even in the ex post perspective which, as a rule, is easier for analyses than the ex ante perspective. Thirdly, we cannot disregard that other tools of technical analysis, or the above-used tools upon applying a different methodology of implementation, could be used to analyze the real estate market.

\section{References}

ACHELIS S. B., 2001, Technical Analysis from A to Z. McGraw Hill, NY, USA. 
ACZEL A., 2011. Statystyka w zarządzaniu (Statistics in Management), PWN, Warszawa.

ARMs R.W., 1997, Znaczenie wolumenu (The Significance of Volume), WIG-Press, Warsaw.

AugustyniaK H., ŁAsZeK J., OlsZeWSKI K., WASZCZUK J., 2012, Cycles on the Housing and Commercial Real Estate Market, Risks and the Need for Appropriate and Prudent Valuation, MPRA Paper, No. 41070.

BARAŃSKA A., 2008, Metody jakościowe i ilościowe na ustugach wyceny nieruchomości (Qualitative and Quantitative Methods in Real Estate Valuation Services), Acta Scientiarum Polonorum, Geodesia et Descriptio Terrarum, No. 7(2), pp. 3-13.

BARBERIS N., 2011, Psychology and the Financial Crisis of 2007-2008, Available at SSRN 1742463.

BARBERIS N., 2013, Psychology and the Financial Crisis of 2007-2008, pp. 15-28. In: M. Haliassos (ed.). Financial innovation: too much or too little? MIT Press.

BeŁej M., CELLMER R., 2014, The Effect of Macroeconomic Factors on Changes in Real Estate Prices on Unstable Markets - Response and Interaction, Acta Scientiarum Polonorum, Seria Oeconomia, No. 13(2), pp. 5-16.

BlANCHARD O., 2009, The Crisis: Basic Mechanisms, and Appropriate Policies, Working Papers, International Monetary Fund, No. WP/09/80.

BOLLINGER J., 1992, Using Bollinger Bands. Stocks \& Commodities, No. 10(2), pp. 47-51.

BRUEGGEMAN W. B., FISHER J.D., 2008, Real Estate Finance \& Investments, 14 ed., McGraw-Hil, Irwin. NY, USA.

BRZEZICKA J., WIŚNIEWSKI R., 2016a, Information Cascade on the Real Estate Market, unpublished research.

BRZEZICKA J., WiŚNIEWSKI R., 2016b, Translocality on the Real Estate Market, Land Use Policy, no. 55, pp. 166-181.

BRyX M., MAtKowsKi R., 2002, Inwestycje w nieruchomości (Investments in Real Estate), Poltext, Warszawa.

CASE K.E., Quigley J.M., SHILleR R.J., 2005, Comparing Wealth Effects: the Stock Market Versus the Housing Market, Advances in Macroeconomics, No. 5(1), pp. 1-32.

CELLMER R., SzCZEPANKOWSKA K. 2014, Simulation Modeling in a Real Estate Market, 9th International Conference "Environmental Engineering" Vilnius Gediminas Technical University, May 2223, www.enviro.vgtu.lt. http://dx.doi.org/10.3846/enviro.2014.113

DeLisLe J.R., 2002, Real Estate and the Capital Markets: A Transitional Period of Spatial Market/Capital Market Convergence, Appraisal Journal, No. 70(2), pp. 121-131.

Dow C.H., 1920, Scientific Stock Speculation (The Magazine of Wall Street), NY, USA.

EDWARds R. D., MAGEE J., BASSETTI W.C. 2007. Technical Analysis of Stock Trends, CRC Press, Taylor \& Francis Group, FL, USA.

ELDRED G.W., 2009, Investing in Real Estate, 6th ed., John Wiley \& Sons, Inc., Hoboken, NJ, USA.

ElLIS C.A., PARBERY S.A., 2005, Is smarter better? A Comparison of Adaptive, and Simple Moving Average Trading Strategies, Research in International Business and Finance, No. 19(3), pp. 399-411.

Gately E., 1998, Forecasting Profits Using Price and Time (Vol. 9), John Wiley \& Sons, NY, USA.

Geltner D., Miller N., Clayton J., EichHoltz P.M.A., 2010, Commercial Real Estate Analysis and Investments, 2nd Edition, South-Western Educational Publishing, USA.

GDAKOWICZ A., 2014, The Application of Japanese Candlestick Charting on the Residential Real Estate Market, Real Estate Management and Valuation, No. 22(4), pp. 27-34.

GDAKOWICZ A., 2015, Wykresy świecowe rynku nieruchomości mieszkaniowych (Candlestick Charting of Residential Real Estate Market), Zeszyty Naukowe Uniwersytetu Szczecińskiego (Scientific Journals of the University of Szczecin). Finanse, Rynki finansowe. Ubezpieczenia (Finances, Financial Markets. Insurance)s, No. 75, pp. 149-158.

GunaseKarage A., POWER D.M., 2001, The Profitability of Moving Average Trading Rules in South Asian Stock Markets, Emerging Markets Review, No. 2(1), pp. 17-33.

GyOURKO J., KeIM D. B., 1992, What does the Stock Market Tell us about Real Estate Returns? Real Estate Economics, No. 20(3), pp. 457-485.

HotT C., Monnin P., 2008, Fundamental Real Estate Prices: An Empirical Estimation with International Data, The Journal of Real Estate Finance and Economics, No. 36(4), pp. 427-450.

KRZYWDA M., 201, GPW II. Akcje i analiza fundamentalna w praktyce (GPW II. Stocks and Fundamental Analysis in Practice), Wydawnictwo Złote Myśli (Golden Thoughts Publishing), Gliwice, Poland.

KUCHARSKA-STASIAK E., 2006, Nieruchomość w gospodarce rynkowej (Real Estate in the Market Economy), PWN (Polish Scientific Publishers), Warsaw, Poland. 
KUCHARSKA-STASIAK E., Schneider B., Załęczna M., 2009, Methodology for Local and Regional Real Estate Market, University of Lodz Press, Łódź, Poland.

Kulesza S., BeŁeJ M., 2014, Dynamics of the Real Estate Prices in the Light of the Catastrophe Theory, Folia Oeconomica, No. 3(302), pp. 211-221.

Kulesza S., BeŁej M., 2015, Local Real Estate Markets in Poland as a Network of Damped Harmonic Oscillators, Acta Physica Polonica A, No. 127 (2015), No. 3-A, pp. 99- 102. DOI:10.12693/ APhysPolA.127.A-99.

LiU W., HuAng X., \& ZHeng W., 2006, Black-Scholes' Model and Bollinger Bands, Physica A: Statistical Mechanics and its Applications, No. 371(2), pp. 565-571.

ŁUNIEWSKA M., 2012, Ekonometria finansowa: analiza rynku kapitałowego (Financial Econometrics: Analysis of Capital Market), PWN, Warszawa.

MuRPHY J.J., 1998, Międzyrynkowa analiza techniczna (Cross-market Technical Analysis), WIG-Press, Warsaw.

MurPHY J.J,. 1999, Technical Analysis of the Financial Market. A Comprehensive Guide to Trading Methods and Applications, New York Institute of Finance, NY, USA.

NeLson S.A., 1903, The A B C of Stock Speculation, S.A. Nelson Publisher, NY, USA.

NisON S., 1994, Beyond Candlesticks: New Japanese Charting Techniques Revealed (Vol. 56), John Wiley \& Sons.

Osler C.L., Chang P.H., 1995, Head and Shoulders: Not just a Flaky Pattern, FRB of New York staff report, No. 4, August.

PANFIL M., SZABLEWSKI A., 2013, Dylematy wyceny przedsiębiorstwa (Dillemas in Enterprise Valuation) Wydawnictwo Poltext (Poltext Publishing), Warsaw.

Plummer T., 2009, Forecasting Financial Markets: the Psychology of Successful Investing, Kogan Page Publishers, London and Philadelphia.

RENIGIER-BIŁOZOR M., 2013, Structure of a Decision Support Subsystem in Real Estate Management, Folia Oeconomica Stetinensia, No. 13(1), pp. 56-75.

RODRIGUE, J-P et al., 2013, The Geography of Transport Systems, Hofstra University, Department of Global Studies \& Geography, http://people.hofstra.edu/geotrans. Alternatively, the book can also be cited: Rodrigue, J-P., 2013, The Geography of Transport Systems, Third Edition, New York: Routledge.

ROEHNER B.M., 1999, Spatial Analysis of Real Estate Price Bubbles: Paris, 1984-1993, Regional Science and Urban Economics, No. 29(1), pp. 73-88.

Roubini N., MinM S., 2010, Crisis Economics: A Crash Course in the Future of Finance, Penguin, NY, USA.

SHILler R.J., 1990, Speculative Prices and Popular Models, The Journal of Economic Perspectives, No. 4(2), pp. 55-65.

Qi S., WAN Q., ZHANG Y., 2011, Market Trend Forecasting of Real Estate Base on K- line Theory and Bollinger Bands, Journal of Wuhan University of Technology (Information \& Management Engineering), No. 33(4), pp. 622-625.

SHILLER R. J., 2009, Unlearned Lessons from the Housing Bubble, The Economists' Voice, No. 6(7), pp. 1-2.

SORNETTE D., WoODARD R., 2010, Financial Bubbles, Real Estate Bubbles, Derivative Bubbles, and the Financial and Economic Crisis (pp. 101-148), IN: Takayasu, M., Takayasu, H., \& Watanabe, T. Econophysics Approaches to Large-Scale Business Data and Financial Crisis. Springer, Tokyo, Japan.

STANISZ A., 2006, Przystęny kurs statystyki: z zastosowaniem STATISTICA PL na przykładach z medycyny (An Accessible Coarse in Statistics: with Applying STATISTICA PL on Examples from the Field of Medicine), Statystyki podstawowe (Basic Statistics), StatSoft, Kraków.

SzYSZKA A., 2013, Behavioral Finance and Capital Markets: How Psychology Influences Investors and Corporations, Palgrave Macmillan, NY, USA.

Tsatsaronis K.., ZHU H., 2004, What Drives Housing Price Dynamics: Cross-Country Evidence, BIS Quarterly Review, March.

WAGNER G. S., MATHENY B.L., 1994, Trading Applications of Japanese Candlestick Charting, Vol. 38, John Wiley \& Sons.

WidŁAK M., AugustyniaK H., ŁASZeK J., OlSZEWSKI K., 2013, Analiza sektora nieruchomości w Polscemonitoring cen, Bezpieczny Bank (Analsyis of the Real Estate Sector in Poland - Monitoring Prices, Safe Bank), No. 4(53), pp. 124-203. 
ZIELONKA P., 2006, Giełda i psychologia. Behawioralne aspekty inwestowania na rynku papierów wartościowych (The Stock Market and Psychology. Behavioral Aspects of Investing in the Securities Market), Wydawnictwo CeDeWu (CeDeWu Publishing House), Warsaw.

ZHOU W.X., SORNETTE D., 2006, Is there a Real-Estate Bubble in the US?. Physica A: Statistical Mechanics and its Applications, No. 361(1), 297-308.

ZYGA J., 2015, Search for Dissimilarity Factors for Nominally Indiscernible Facilities, Real Estate Management and Valuation, No. 23(3), pp. 65-72.

ŹRÓBEK S. (Ed.), 2006, Metodyka określania wartości rynkowej nieruchomości: przykłady operatów szacunkowych (Methodology for Determining the Market Value of Real Estate: Examples of Appraisal Reports), Educaterra, Olsztyn. 